\title{
Spacial distribution of fertigated coffee root system
}

\section{Distribuição espacial do sistema radicular do cafeeiro fertirrigado}

\author{
Marcelo Rossi Vicente ${ }^{1 *}$, Everardo Chartuni Mantovani ${ }^{2}$, André Luís Teixeira Fernandes ${ }^{3}$, \\ Júlio César Lima Neves ${ }^{4}$ Edmilson Marques Figueredo5, Fábio Teixeira Delazari ${ }^{6}$
}

\author{
1Instituto Federal de Educação, Ciência e Tecnologia do Norte de Minas Gerais/IFNMG, Salinas, MG, Brasil \\ ${ }^{2}$ Universidade Federal de Viçosa/UFV, Departamento de Engenharia Agrícola, Viçosa, MG, Brasil \\ ¿Universidade de Uberaba/Uniube, Uberaba, MG, Brasil \\ ${ }^{4}$ Universidade Federal de Viçosa/UFV, Departamento de Solos, Viçosa, MG, Brasil \\ ${ }^{5}$ Bahia Farm Show, Barreiras, BA, Brasil \\ Universidade Federal de Viçosa/UFV, Departamento de Fitotecnia, Viçosa, MG, Brasil \\ *Corresponding author: marcelo.vicente@ifnmg.edu.br \\ Received in May 20, 2016 and approved in October 31, 2016
}

\begin{abstract}
The development of coffee plant root system changes when subjected to drip irrigation and fertigation. This work aimed to evaluate the effects of different levels of fertigation on the development of coffee root system by drip irrigation in western Bahia. The experiment was carried out with Catuaí Vermelho IAC 144 coffee plants, of about 3.5 years of age, in the "Café do Rio Branco" farm, located in Barreiras - BA, and consisted of a complete randomized blocks design with 3 replicates. Treatments consisted of three levels of nitrogen and potassium fertilization $\left(900 / 800,600 / 500\right.$ and $300 / 250 \mathrm{~kg} \mathrm{ha}^{-1}$ year ${ }^{-1} \mathrm{~N}$ and $\left.\mathrm{K}_{2} \mathrm{O}\right)$, weekly distributed, by means of fertigation, throughout the process. After the fourth harvest, coffee root system was evaluated, and root length density (RLD) and root density (RD) were determined at different sampled layers. The highest root concentration, root length density (RLD), and root density (RD) were observed in the superficial layers of soil $\left(0-20 \mathrm{~cm}\right.$ ), and under the dripline (30 and $70 \mathrm{~cm}$ from the orthotropic branch). Results showed that the lower the $\mathrm{N}$ and $\mathrm{K}_{2} \mathrm{O}$ levels, the higher was the development (RLD and RD) of the coffee root system.
\end{abstract}

Index terms: Coffea arabica L.; irrigation; nitrogen fertilization; potassium fertilization.

\begin{abstract}
RESUMO
O desenvolvimento do sistema radicular do cafeeiro é alterado quando submetido à irrigação localizada e fertirrigação. Este trabalho foi desenvolvido com o objetivo de avaliar os efeitos de diferentes doses de fertirrigação sobre o desenvolvimento do sistema radicular do cafeeiro irrigado por gotejamento na região Oeste da Bahia. Realizou-se o trabalho na fazenda Café do Rio Branco, localizada em Barreiras - BA, em cafeeiros de aproximadamente 3,5 anos de idade, da variedade Catuaí IAC 144. O experimento foi montado em um esquema fatorial 3 × 3, sendo três níveis de adubação nitrogenada e potássica (900/800, 600/500 e 300/250 kg ha-1 ano-1 de N e K ${ }_{2} \mathrm{O}$ ), em 3 parcelamentos mensais de fertirrigação (2, 4 e 8 vezes). Após a quarta safra, o sistema radicular do cafeeiro foi avaliado e a densidade de comprimento radicular (DCR) e densidade radicular (DR) em diferentes camadas amostradas foram determinadas. A maior concentração de raízes, densidade de comprimento radicular (DCR) e densidade radicular (DR) foi obtida nas camadas superficiais $(0-20 \mathrm{~cm})$ e sob a linha lateral (30 e $70 \mathrm{~cm}$ de distância do ramo ortotrópico). As menores doses de $\mathrm{N}$ e $\mathrm{K}_{2} \mathrm{O}$ propiciaram maior desenvolvimento (DCR e DR) do sistema radicular do cafeeiro.
\end{abstract}

Termos para indexação: Coffea arabica L.; irrigação; adubação nitrogenada; adubação potássica.

\section{INTRODUCTION}

Irrigation allowed the expansion of coffee cultivated areas into regions considered marginal to its cultivation. These regions are limited by high temperatures and scarce rainfall (Dominghetti et al., 2014; Silveira et al., 2015).

This technology ensures adequate water supply at critical periods of water requirements, besides maximizing efficiency in the application of fertilizers by means of fertigation (Dominghetti et al., 2014). The increase of fertilizer efficiency is one of the main advantages of fertigation (Guimarães et al., 2011; Rezende et al., 2010; Sobreira et al., 2011).

Compared with the conventional fertilization system, fertigation increases yield, improves the quality of coffee plants fruits, reduces costs with labor, and increases efficiency of soil management (Carvalho et al., 2010; Pereira et al., 2010; Sobreira et al., 2011).

However, the benefits of this technique are limited due to the lack of specific information in relation to coffee plants, particularly regarding the level and the number of applications per year (Sobreira et al., 2011). 
A very important factor when working with irrigation/fertigation by drip is the crop root system.

Coffea arabica root system is concentrated under the canopy projection (Motta et al., 2006), reaching $50 \mathrm{~cm}$ depth (Rena; Guimarães, 2000).

Root development is complex and is influenced by various factors (Rena et al., 2002; Silva et al., 2010). Several researchers state that the conformation of the root system depends primarily on the genetic load of the plant, and then, on the properties and characteristics of the soil, such as fertility, water content, aeration, density, mechanical strength, among others.

Fertigation provides more root concentration in the superficial layers since fertilizers distribution is more concentrated in that region (Barreto et al., 2006; Ronchi et al., 2015).

Considering mineral and organic fertilization, nitrogen is the most important element for the longitudinal and radial growth of the roots. However, different potassium levels do not significantly affected root growth (Kumar, 1979).

This work aimed to study the effects of different levels and plots of drip fertigation on coffee root system in western Bahia conditions.

\section{MATERIAL AND METHODS}

An experiment was carried out with Catuaí Vermelho IAC 144 coffee plants, of approximately 3.5 years of age, irrigated by a dripline, in Café Rio Branco farm (Latitude: $11^{\circ} 48^{\prime} 01^{\prime \prime}$ South, Longitude: 45035'50" West; at $735 \mathrm{~m}$ asl), located in Barreiras, state of Bahia, in a Quatzipsammment Soil with sandy loam texture. The study was carried out from November 2004 to May 2008.

\section{Physical characterization of the soil of the experimental area}

Table 1 shows the textural analysis of the area where the experiment was set. Table 2 shows the values of soil water retention for the several water tensions. Soil moisture corresponding to 5 and $1540 \mathrm{kPa}$ were considered as field capacity and permanent wilting point, respectively.
Table 1:Granulometric composition, textural classification, and soil density of the experimental area.

\begin{tabular}{cccccc}
\hline $\begin{array}{c}\text { Depth } \\
(\mathrm{cm})\end{array}$ & \multicolumn{2}{c}{$\begin{array}{c}\text { Granulometric } \\
\text { composition (\%) }\end{array}$} & $\begin{array}{c}\text { Soil } \\
\text { density }\end{array}$ & $\begin{array}{c}\text { Textural } \\
\text { classification }\end{array}$ \\
\cline { 2 - 5 } & Sand & Silt & Clay & $\left(\mathrm{g} / \mathrm{cm}^{3}\right)$ & \\
\hline $0-20$ & 65.53 & 2.23 & 32.24 & 1.57 & Sandy clay loam \\
$20-40$ & 63.37 & 2.86 & 33.78 & 1.57 & Sandy clay loam \\
$40-60$ & 57.20 & 2.83 & 39.97 & 1.47 & Sandy clay \\
\hline
\end{tabular}

Mean values of field capacity and wilting point of the soil, in the $0-60 \mathrm{~cm}$ layer, were 17.57 and $11.46 \%$ in weight, respectively.

\section{Treatment description}

The experiment was carried out with coffee plants planted in December 2002, in $3.80 \times 0.5 \mathrm{~m}$ spacing (5263 plants $\mathrm{ha}^{-1}$ ), irrigated by drip, with $2.3 \mathrm{~L} \mathrm{~h}^{-1}$ flow rate, spaced $0.75 \mathrm{~m}$ apart.

Experimental plots were composed of 20 plants $(10 \mathrm{~m})$, and the 10 central plants were considered the useful plot. The experiment consisted of randomized blocks design with three replicates. Table 3 shows more details regarding the treatments.

Table 4 presents the fertilizer distribution over the experimentation years, recommended for western Bahia (Santinato; Fernandes, 2002). Urea was used as nitrogen source, and potassium chloride was used as potassium source.

\section{Irrigation and Water Management}

Coffee water demand was determined with the aid of the Irriplus software, using adjustment coefficients on the reference evapotranspiration (ETo). Gross irrigation depth was calculated using a water balance, in which the water inputs were irrigation and effective rainfall, and outputs were crop evapotranspiration (ETc) and percolation below the depth considered in the root system. Equation 1 was used to estimate evapotranspiration (Mantovani et al., 2013).

Table 2: Soil water retention values (\% moisture in weight) for different levels of water tension in the soil for the experimental area.

\begin{tabular}{ccccccccccc}
\hline $\begin{array}{c}\text { Layers } \\
(\mathrm{cm})\end{array}$ & 0.1 & 1 & 2 & 5 & 10 & 20 & 33 & 50 & 70 & 1540 \\
\hline $0-20$ & 26.85 & 21.80 & 21.19 & 16.88 & 15.13 & 13.93 & 13.49 & 12.71 & 12.10 & 11.16 \\
$20-40$ & 27.00 & 23.35 & 21.54 & 16.56 & 14.85 & 13.82 & 13.34 & 12.76 & 12.22 & 11.39 \\
$40-60$ & 29.72 & 24.99 & 24.14 & 19.27 & 16.57 & 14.93 & 14.36 & 13.51 & 12.72 & 11.84 \\
\hline
\end{tabular}


Table 3: Description of the different treatments of $\mathrm{N}$ and $\mathrm{K}_{2} \mathrm{O}$ levels and plots, Barreiras, BA.

\begin{tabular}{|c|c|c|c|c|}
\hline \multirow{2}{*}{ Treatment } & \multicolumn{2}{|c|}{ Levels (kg ha-1 year-1) } & \multirow{2}{*}{ Plot } & \multirow{2}{*}{ Number of monthly applications } \\
\hline & $\mathrm{N}$ & $\mathrm{K}_{2} \mathrm{O}$ & & \\
\hline 1 & 900 & 800 & 1 per week & 4 \\
\hline 2 & 600 & 500 & 1 per week & 4 \\
\hline 3 & 300 & 250 & 1 per week & 4 \\
\hline
\end{tabular}

Table 4: Fertilizers distribution over the experimentation years.

\begin{tabular}{ccccccccccccc}
\hline Nutrient & Jan & Feb & Mar & Apr & May & Jun & Jul & Aug & Sep & Oct & Nov & Dec \\
\hline $\mathrm{N}$ & $10 \%$ & $10 \%$ & $10 \%$ & $10 \%$ & $5 \%$ & $5 \%$ & $5 \%$ & $5 \%$ & $10 \%$ & $10 \%$ & $10 \%$ & $10 \%$ \\
$\mathrm{~K}_{2} \mathrm{O}$ & $15 \%$ & $15 \%$ & $15 \%$ & $10 \%$ & $5 \%$ & $0 \%$ & $0 \%$ & $5 \%$ & $5 \%$ & $10 \%$ & $10 \%$ & $10 \%$ \\
\hline
\end{tabular}

$E T c=E T o \times K c \times K s \times K l$

in which ETc: crop evapotranspiration, in $\mathrm{mm} \mathrm{d}^{-1}$; ETo: reference evapotranspiration, in $\mathrm{mm} \mathrm{d}^{-1}$; Kc: crop coefficient, dimensionless; Ks: water stress coefficient, dimensionless; and $\mathrm{Kl}$ : coefficient related to the percentage of ground covered by the crop, dimensionless.

The estimate method of ETo used by Irriplus, according to the available weather elements (solar radiation, average temperature, wind speed, relative humidity) was carried out by the Penman-Monteith-FAO 56 method (Allen et al., 2006). Meteorological data used for the experiment were obtained from an automatic agrometeorological station (Davis, Vantage Pro model), located in the farm.

Ks was calculated using the logarithmic model (Mantovani et al., 2013), in function of the percentage of wet or shaded area (Keller; Bliesner, 1990; Mantovani et al., 2013).

Values of crop coefficient (Kc), percentage of shaded area (P), and effective root depth used in this experiment were $1.0,50 \%$ and $0.60 \mathrm{~m}$, respectively. Percentage of wet area was $30 \%$.

Figure 1 shows the reference evapotranspiration (monthly average and maximum), and the monthly average temperature, between November 2004 and May 2008. During this period, the cumulative value of ETo was of $5,444 \mathrm{~mm}$ (mean of $4.20 \mathrm{~mm} \mathrm{~d}^{-1}$ and $1,485 \mathrm{~mm} \mathrm{year}^{-1}$ ). October 2007 had the highest ETo mean $\left(5.85 \mathrm{~mm} \mathrm{~d}^{-1}\right)$, and November 2007 had the maximum daily ETo (8.76 $\left.\mathrm{mm} \mathrm{d}^{-1}\right)$. The average temperature of the studied period was $22.9^{\circ} \mathrm{C}$, and the highest monthly average $\left(25.7^{\circ} \mathrm{C}\right)$ was obtained in October 2005.
Total irrigation depth applied during the studied period (November 2004 to May 2008) was $3028 \mathrm{~mm}$. Total rainfall was $3715.5 \mathrm{~mm}$.

\section{Coffee root system evaluation}

For root system samples, a soil probe of $72 \mathrm{~mm}$ diameter and $1.30 \mathrm{~m}$ length was used (Guan et al., 2015; Quanqi et al., 2010). Samples were determined at 0.30, 0.70, and $1.10 \mathrm{~m}$ from the main orthotropic branch, on both sides of the plant, and perpendicular to the row (Figure 2), and taken from layers of $0-0.10 ; 0.10-0.20 ; 0.30-0.40 ; 0.50$ $0.60 ; 0.70-0.80$; and $0.90-1.00 \mathrm{~m}$ depth. Sampling was carried out in one plant of each plot of the treatments, in three replications, in October 2008, i.e., forty-three months after treatment application.

After removal, soil and root samples were placed on a $2 \mathrm{~mm}$ mesh sieve. With the aid of water jets, roots were separated from the soil.

Afterwards, roots were kept in 50\% alcohol solution, and then classified according to the diameter, considering coarse roots $(>3 \mathrm{~mm})$; medium roots, or support of the absorbing roots ( 1 to $3 \mathrm{~mm}$ ); and fine roots, or absorbing roots $(<1 \mathrm{~mm}$ ) (Rena et al., 2002). After classification, roots were placed on transparency sheets for scanning, with 300 dpi resolution in JPG files, and were processed in order to obtain roots length and diameter with the aid of the Quaantroot software (Guan et al., 2015; Quanqi et al., 2010).

Subsequently, dry mass was determined in an analytical scale, after drying in an oven at $60{ }^{\circ} \mathrm{C}$ for sufficient time to achieve roots constant mass.

Roots length allowed determining root length density (RLD), by Equation 2, and roots dry mass allowed determining root density (RD), by Equation 3 . 


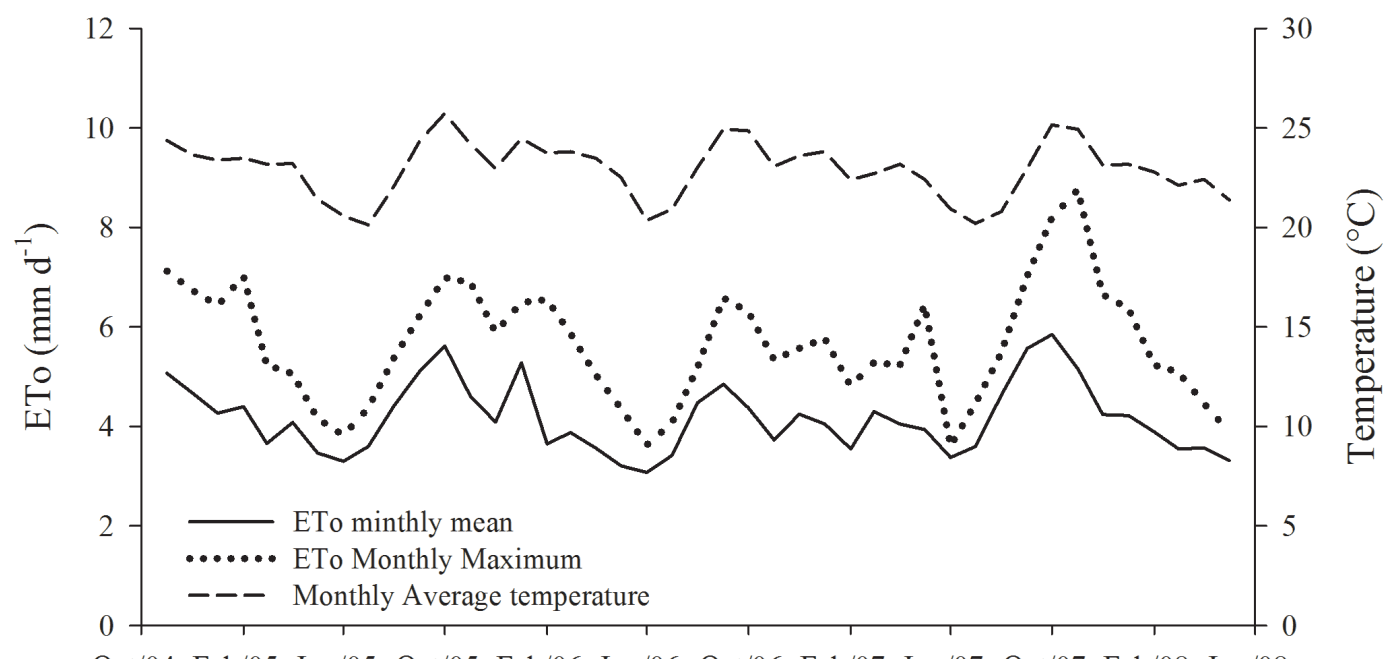

Oct/04 Feb/05 Jun/05 Oct/05 Feb/06 Jun/06 Oct/06 Feb/07 Jun/07 Oct/07 Feb/08 Jun/08

Date (month)

Figure 1: Reference evapotranspiration (monthly average and maximum) in $\mathrm{mm}^{-1}$, and monthly average temperature in ${ }^{\circ} \mathrm{C}$.

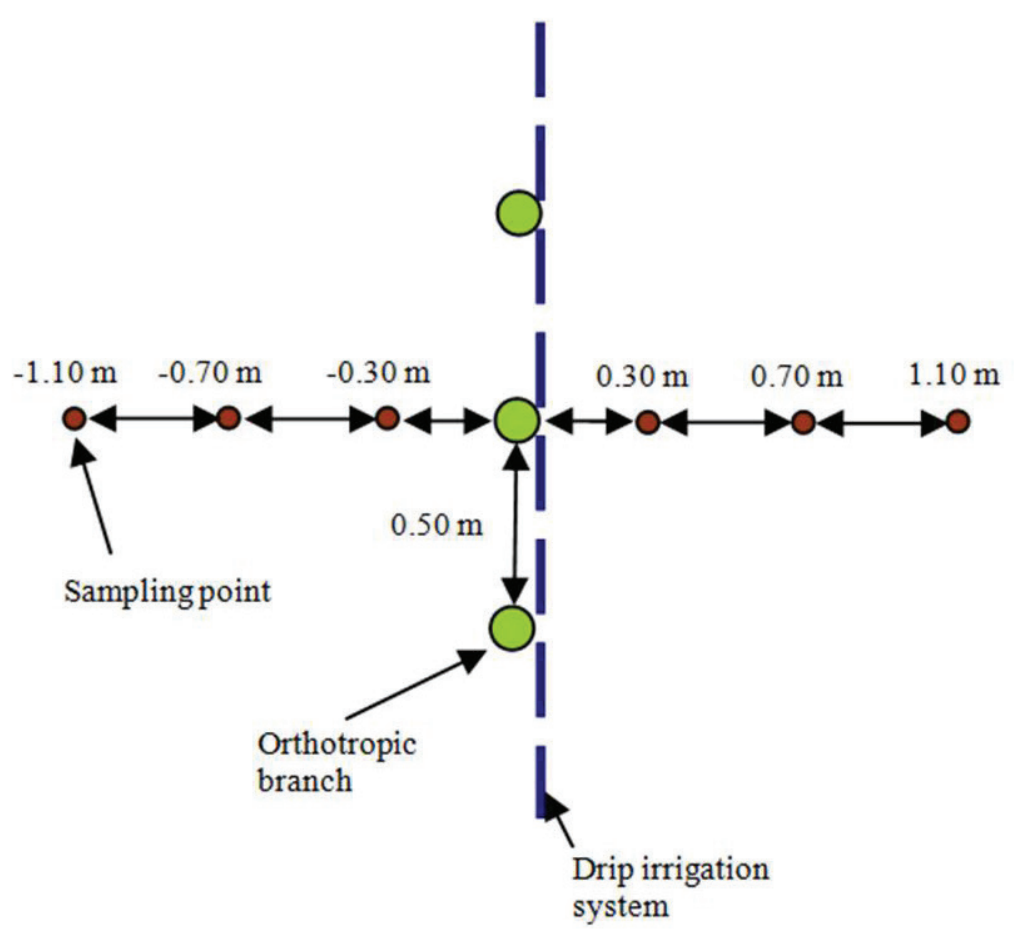

Figure 2: Positions of samplings in relation to the planting line and the dripline for the evaluation of coffee root system. 


$$
R D L=\frac{L_{R}}{V_{A}}
$$

in which RLD: root length density $\left(\mathrm{cm} \mathrm{cm}^{-3}\right) ; \mathrm{L}_{\mathrm{R}}$ : total length of sampled roots $(\mathrm{cm})$; and $\mathrm{V}_{\mathrm{A}}$ : total volume of sampled soil $\left(\mathrm{cm}^{-3}\right)$.

$$
R D=\frac{M_{R}}{V_{R}}
$$

in which RD: root density $\left(\mathrm{g} \mathrm{dm}^{-3}\right) ; \mathrm{M}_{\mathrm{R}}$ : root dry mass $(\mathrm{g})$; and $\mathrm{V}_{\mathrm{A}}$ : total volume of sampled soil $\left(\mathrm{dm}^{-3}\right)$.

\section{Statistical analysis}

The split plot scheme was used for data analyses of root length density (RLD) and root density (RD), in which the three treatments constituted the plot, and depth and sampling distance constituted the subplot treatments.

The $\mathrm{F}$ test at $5 \%$ probability was used for analysis of variance, and means were compared using the Tukey test at $5 \%$ probability.

The SAEG 9.0 statistical software, developed by the Federal University of Viçosa, was used for statistical analysis.

\section{RESULTS AND DISCUSSION}

\section{Root system analysis}

Significant effect $(\mathrm{p}<0.05)$ of $\mathrm{N}$ and $\mathrm{K}_{2} 0$ levels on the development of coffee root system (fine roots) was observed, as confirmed by the RLD and RD values (Table 5).

The lower the $\mathrm{N}$ and $\mathrm{K}_{2} \mathrm{O}$ levels, the higher was the development of the root system. Thus, lower levels are compensated by higher growth. These results confirm the claim that under conditions of low nutrient availability, root production may increase in some coffee cultivars (Alves et al., 2011).

Results showed that coffee with moderate nutritional deficiency of $\mathrm{N}$ and $\mathrm{K}_{2} \mathrm{O}$ have higher root growth when compared with better nourished coffee trees, possibly due to allocation of carbohydrates to the root system.

Results presented in Table 6 corroborate the above statements, since levels $\mathrm{x}$ sampled layers interaction was significant $(\mathrm{p}<0.05)$ for fine roots $\mathrm{RD}$. Coffee plants subjected to $300 / 250$ and $600 / 500\left(\mathrm{~N} / \mathrm{K}_{2} \mathrm{O}\right)$ levels produced more roots in the $0-10 \mathrm{~cm}$ depth layer than those subjected to $900 / 800\left(\mathrm{~N} / \mathrm{K}_{2} \mathrm{O}\right)$.
Table 5: Root length density - RLD $\left(\mathrm{cm} \mathrm{cm}^{-3}\right)$ and root density - RD $\left(\mathrm{g} \mathrm{dm}^{-3}\right)$ of fine roots for the different $\mathrm{N}$ and $\mathrm{K}_{2} \mathrm{O}$ levels.

\begin{tabular}{ccl}
\hline $\begin{array}{c}\text { Levels }\left(\mathrm{kg} \mathrm{ha}^{-1} \text { year }^{-1}\right) \\
\left(\mathrm{N} / \mathrm{K}_{2} \mathrm{O}\right)\end{array}$ & $\mathrm{RLD}\left(\mathrm{cm} \mathrm{cm}^{-3}\right)$ & $\mathrm{RD}\left(\mathrm{g} \mathrm{dm}^{-3}\right)$ \\
\hline $300 / 250$ & $2.47 \mathrm{~A}$ & $0.5545 \mathrm{~A}$ \\
$600 / 500$ & $1.94 \mathrm{~B}$ & $0.4546 \mathrm{~B}$ \\
$900 / 800$ & $1.94 \mathrm{~B}$ & $0.4991 \mathrm{AB}$ \\
\hline
\end{tabular}

Means followed by the same letter in the column do not differ by theTukey test $(\mathrm{P}<0.05)$.

Table 6: Root density - RD ( $\mathrm{g} \mathrm{cm}^{-3}$ ) of fine roots for sampled layers, in function of $\mathrm{N}$ and $\mathrm{K}_{2} \mathrm{O}$.

\begin{tabular}{cccc}
\hline \multirow{2}{*}{$\begin{array}{c}\text { Layer } \\
(\mathrm{cm})\end{array}$} & \multicolumn{3}{c}{ Levels $\left(\mathrm{kg} \mathrm{ha}^{-1}\right.$ year $\left.^{-1}\right)\left(\mathrm{N} / \mathrm{K}_{2} \mathrm{O}\right)$} \\
\cline { 2 - 4 } $0-10$ & $300 / 250$ & $600 / 500$ & $900 / 800$ \\
$10-20$ & $0.02 \mathrm{~A} \mathrm{a}$ & $1.90 \mathrm{~A} \mathrm{a}$ & $1.62 \mathrm{~B} \mathrm{a}$ \\
$30-40$ & $0.29 \mathrm{~A} \mathrm{c}$ & $0.25 \mathrm{~A} \mathrm{bc}$ & $0.31 \mathrm{~A} \mathrm{bc}$ \\
$50-60$ & $0.19 \mathrm{Ac}$ & $0.14 \mathrm{Ac}$ & $0.17 \mathrm{~A} \mathrm{bc}$ \\
$70-80$ & $0.16 \mathrm{Ac}$ & $0.13 \mathrm{~A} \mathrm{c}$ & $0.14 \mathrm{~A} \mathrm{bc}$ \\
$90-100$ & $0.11 \mathrm{Ac}$ & $0.10 \mathrm{~A} \mathrm{c}$ & $0.11 \mathrm{~A} \mathrm{c}$ \\
\hline
\end{tabular}

Means followed by the same uppercase letter (line) and by the same lowercase letter (column) do not differ by the Tukey test at $5 \%$ probability.

There was significant interaction effect of sampled levels and distances $(\mathrm{p}<0.5)$ for RLD (fine and medium roots) and RD (fine roots only). Table 7 and 8 shows the RLD and RD values, respectively, for sampled layers and levels. The largest concentration of roots was observed in the fertirrigated range, under the dripline, at distances of 30 and $70 \mathrm{~cm}$. These results are consistent with those presented by Rena et al. (2002), who observed in 6 yearsold coffee plants, in Ponte Nova - MG, the highest root volume on the side where it is usually fertilized.

Table 7 and 8 show that both RLD and RD, for fine roots at distance of $70 \mathrm{~cm}$ and at a rate of $300 / 250 \mathrm{~N} / \mathrm{K}_{2} \mathrm{O}$ were superior to the other sampled layers, demonstrating greater development of coffee root system under lower $\mathrm{N}$ and $\mathrm{K}_{2} \mathrm{O}$.

There was isolated effect on the sampled distance on RLD and RD for fine and medium roots, as shown in Table 9. Higher concentration of roots was observed at distances of 30 and $70 \mathrm{~cm}$ under the dripline, i.e., under wet and fertigation range, justified by the increased concentration of nutrients and higher soil moisture levels. Similar results were found by Sakai et al. (2015), who observed that irrigated treatments showed higher 
concentration of roots below the tree canopy and near the drip emitter.

Isolated effect was also observed in sampled layer on the RLD and RD for fine and medium roots (Table 10). As expected, due to the higher concentration of organic matter, nutrients, and soil moisture levels, superficial layers (0-10 and 10-20 cm) showed the highest root concentration (RLD and RD) for both fine and medium roots.

Values observed for RD, both for fine and medium roots, in all the layers, are in agreement with those observed in the literature (Soares et al., 2007). On the other hand, Partelli et al. (2006) observed values of about $7.1 \mathrm{~cm} \mathrm{~cm}^{-3}$ (fine roots) for the $0-20 \mathrm{~cm}$ layer for 'Conilon' coffee plants, from seeds and cuttings, in the municipality of Vila Valério, ES. The authors also observed reduction in roots density in function of the layer depth.

Several authors found higher roots concentration in more superficial layers (Garriz, 1978; Sakai et al., 2015; Soares et al., 2007).
There was significant effect $(\mathrm{p}<0.05)$ of distance $x$ sampled layer interaction on RLD and RD. Tables 11 and 12 show RLD (Table 11) and RD (Table 12) means for the different sampled distances and layers.

By analyzing both tables, together with Tables $6,7,9$ and 10, the highest concentration of roots is confirmed in superficial layers and closer to the dripline, where roots find greater availability of nutrients and water, allowing the coffee crop to use more efficiently the water and minerals available. The presence of mulch also contributes to greater root system volume in the upper layers (Cassidy; Kumar, 1984).

Results of the distribution of coffee roots by drip irrigation reinforces the recommendation of fertigation as suitable alternative of fertilizer application to the soil, since greater amount of roots received nutrients in a short period of time, which consequently improved absorption.

Table 7: Root length density - RLD $\left(\mathrm{cm} \mathrm{cm}^{-3}\right)$ of fine and medium roots for different sampled levels and layers.

\begin{tabular}{cllllll}
\hline \multirow{2}{*}{\begin{tabular}{c} 
Levels $\left(\mathrm{kg} \mathrm{ha}^{-1}\right.$ year $\left.^{-1}\right)$ \\
\cline { 2 - 6 }$\left./ \mathrm{K}_{2} \mathrm{O}\right)$
\end{tabular}} & -110 & \multicolumn{7}{c}{ Distance $(\mathrm{cm})$} \\
\hline \multicolumn{7}{c}{ Fine roots } \\
\hline $300 / 250$ & $0.5 \mathrm{Da}$ & $2.33 \mathrm{BCDa}$ & $2.63 \mathrm{BCDa}$ & $3.04 \mathrm{BCa}$ & $4.94 \mathrm{Aa}$ & $1.4 \mathrm{CDa}$ \\
$600 / 500$ & $0.36 \mathrm{Ca}$ & $1.53 \mathrm{BCa}$ & $1.99 \mathrm{BCa}$ & $3.69 \mathrm{ABa}$ & $2.59 \mathrm{ABCb}$ & $1.46 \mathrm{BCa}$ \\
$900 / 800$ & $0.73 \mathrm{Ba}$ & $2.52 \mathrm{Aa}$ & $2.21 \mathrm{Aa}$ & $2.67 \mathrm{Aa}$ & $2.69 \mathrm{Ab}$ & $0.81 \mathrm{Ba}$ \\
\hline \multicolumn{7}{c}{ Medium roots } \\
\hline $300 / 250$ & $0.02 \mathrm{Ca}$ & $0.02 \mathrm{BCa}$ & $0.06 \mathrm{ABCa}$ & $0.06 \mathrm{ABCab}$ & $0.07 \mathrm{ABa}$ & $0.02 \mathrm{BCa}$ \\
$600 / 500$ & $0.01 \mathrm{Ca}$ & $0.02 \mathrm{BCa}$ & $0.05 \mathrm{ABCa}$ & $0.09 \mathrm{ABab}$ & $0.05 \mathrm{ABCa}$ & $0.02 \mathrm{BCa}$ \\
$900 / 800$ & $0.03 \mathrm{Aa}$ & $0.03 \mathrm{Aa}$ & $0.03 \mathrm{Aa}$ & $0.05 \mathrm{Ab}$ & $0.04 \mathrm{Aa}$ & $0.02 \mathrm{Aa}$ \\
\hline
\end{tabular}

Means followed by the same uppercase letter (line) and by the same lowercase letter (column), within the same roots class, do not differ by the Tukey test at $5 \%$ probability.

Table 8: Root density - RD ( $\left.\mathrm{g} \mathrm{dm}^{-3}\right)$ of fine roots for different sampled levels and layers.

\begin{tabular}{|c|c|c|c|c|c|c|}
\hline \multirow{2}{*}{$\begin{array}{c}\text { Levels }\left(\mathrm{kg} \mathrm{ha}^{-1} \text { year }^{-1}\right) \\
\left(\mathrm{N} / \mathrm{K}_{2} \mathrm{O}\right)\end{array}$} & \multicolumn{6}{|c|}{ Distance $(\mathrm{cm})$} \\
\hline & -110 & -70 & -30 & 30 & 70 & 110 \\
\hline \multicolumn{7}{|c|}{ Fine roots } \\
\hline $300 / 250$ & $0.16 \mathrm{D} \mathrm{a}$ & $0.53 \mathrm{BCD}$ a & $0.66 \mathrm{BC}$ a & 0.68 BC ab & $0.98 \mathrm{Aa}$ & $0.31 C D a b$ \\
\hline $600 / 500$ & $0.11 \mathrm{D} \mathrm{a}$ & $0.41 \mathrm{Ca}$ & $0.48 \mathrm{BC}$ a & $0.84 \mathrm{AB} a b$ & $0.71 \mathrm{ABC} b$ & $0.44 \mathrm{BC} a b$ \\
\hline $900 / 800$ & $0.16 \mathrm{D} \mathrm{a}$ & 0.53 BCD a & $0.66 \mathrm{BC}$ a & 0.68 BC ab & $0.98 \mathrm{~A} \mathrm{a}$ & $0.31 C D a b$ \\
\hline
\end{tabular}

Means followed by the same uppercase letter (line) and by the same lowercase letter (column) do not differ by the Tukey test at $5 \%$ probability. 
Table 9: Root length density - RLD $\left(\mathrm{cm} \mathrm{cm}^{-3}\right)$ and root density - RD ( $\left.\mathrm{g} \mathrm{dm}^{-3}\right)$ of fine and medium roots for sampled distances.

\begin{tabular}{cccl}
\hline $\begin{array}{c}\text { Distance } \\
(\mathrm{cm})\end{array}$ & $\begin{array}{c}\text { RLD } \\
\left(\mathrm{cm} \mathrm{cm}^{-3}\right)\end{array}$ & $\begin{array}{c}\text { Distance } \\
(\mathrm{cm})\end{array}$ & $\begin{array}{c}\mathrm{RD} \\
\left(\mathrm{g} \mathrm{dm}^{-3}\right)\end{array}$ \\
\hline 70 & $3.40 \mathrm{~A}$ & 70 & $0.77 \mathrm{~A}$ \\
30 & $3.13 \mathrm{~A}$ & 30 & $0.71 \mathrm{AB}$ \\
-30 & $2.27 \mathrm{~B}$ & -30 & $0.55 \mathrm{BC}$ \\
-70 & $2.12 \mathrm{~B}$ & -70 & $0.51 \mathrm{C}$ \\
110 & $1.22 \mathrm{C}$ & 110 & $0.32 \mathrm{D}$ \\
-110 & $0.53 \mathrm{C}$ & -110 & $0.17 \mathrm{D}$ \\
\hline \multicolumn{5}{c}{ Medium roots } \\
\hline 30 & $0.0654 \mathrm{~A}$ & 30 & $0.3379 \mathrm{~A}$ \\
70 & $0.0526 \mathrm{~A}$ & 70 & $0.2959 \mathrm{AB}$ \\
-30 & $0.0462 \mathrm{AB}$ & -30 & $0.2748 \mathrm{ABC}$ \\
-70 & $0.0244 \mathrm{BC}$ & -70 & $0.1481 \mathrm{BCD}$ \\
110 & $0.0197 \mathrm{C}$ & 110 & $0.0910 \mathrm{CD}$ \\
-110 & $0.0168 \mathrm{C}$ & -110 & $0.0777 \mathrm{D}$ \\
\hline
\end{tabular}

Means followed by the same letter, for RLD and RD, within the roots classes, do not differ by the Tukey test at $5 \%$ probability.
Table 10: Root length density - RLD $\left(\mathrm{cm} \mathrm{cm}^{-3}\right)$ and root density - RD $\left(\mathrm{g} \mathrm{dm}^{-3}\right)$ of fine and medium roots for the sampled layers.

\begin{tabular}{cccc}
\hline $\begin{array}{c}\text { Layer } \\
(\mathrm{cm})\end{array}$ & $\begin{array}{c}\text { RLD } \\
\left(\mathrm{cm} \mathrm{cm}^{-3}\right)\end{array}$ & $\begin{array}{c}\text { Layer } \\
(\mathrm{cm})\end{array}$ & $\begin{array}{c}\text { RD } \\
\left(\mathrm{g} \mathrm{dm}^{-3}\right)\end{array}$ \\
\hline $0-10$ & $8.48 \mathrm{~A}$ & $0-10$ & $1.85 \mathrm{~A}$ \\
$10-20$ & $1.87 \mathrm{~B}$ & $10-20$ & $0.47 \mathrm{~B}$ \\
$30-40$ & $0.94 \mathrm{C}$ & $30-40$ & $0.28 \mathrm{C}$ \\
$50-60$ & $0.56 \mathrm{C}$ & $50-60$ & $0.17 \mathrm{CD}$ \\
$90-100$ & $0.54 \mathrm{C}$ & $70-80$ & $0.14 \mathrm{CD}$ \\
$70-80$ & $0.30 \mathrm{C}$ & $90-100$ & $0.10 \mathrm{D}$ \\
\hline \multicolumn{4}{c}{ Medium roots } \\
\hline $0-10$ & $0.0907 \mathrm{~A}$ & $0-10$ & $0.4610 \mathrm{~A}$ \\
$10-20$ & $0.0494 \mathrm{~B}$ & $10-20$ & $0.3097 \mathrm{~B}$ \\
$30-40$ & $0.0359 \mathrm{BC}$ & $30-40$ & $0.1919 \mathrm{BC}$ \\
$50-60$ & $0.0184 \mathrm{C}$ & $50-60$ & $0.1103 \mathrm{C}$ \\
$70-80$ & $0.0165 \mathrm{C}$ & $70-80$ & $0.0858 \mathrm{C}$ \\
$90-100$ & $0.0142 \mathrm{C}$ & $90-100$ & $0.0666 \mathrm{C}$ \\
\hline
\end{tabular}

Means followed by the same letter, for RLD and RD, within the roots classes, do not differ by the Tukey test at $5 \%$ probability.

Table 11: Root length density - RLD $\left(\mathrm{cm} \mathrm{cm}^{-3}\right)$ of fine and medium roots for the sampled distances and layers.

\begin{tabular}{|c|c|c|c|c|c|c|}
\hline \multirow{2}{*}{$\begin{array}{l}\text { Layer } \\
(\mathrm{cm})\end{array}$} & \multicolumn{6}{|c|}{ Distance $(\mathrm{cm})$} \\
\hline & -110 & -70 & -30 & 30 & 70 & 110 \\
\hline \multicolumn{7}{|c|}{ Fine roots } \\
\hline $0-10$ & $1.7 \mathrm{Ea}$ & $9.37 \mathrm{Ca}$ & $9.03 \mathrm{Ca}$ & $14.48 \mathrm{Aa}$ & $12.33 \mathrm{Ba}$ & $3.94 \mathrm{Da}$ \\
\hline $10-20$ & $0.58 \mathrm{Ca}$ & $1.56 \mathrm{ABCb}$ & $2.47 \mathrm{ABCbc}$ & $2.28 \mathrm{ABCbc}$ & 3.27 ABCbc & $1.05 \mathrm{BCb}$ \\
\hline $30-40$ & $0.21 \mathrm{Aa}$ & $0.67 \mathrm{Ab}$ & $1.15 \mathrm{Abc}$ & $0.88 \mathrm{Abc}$ & $2.03 \mathrm{Abc}$ & $0.71 \mathrm{Ab}$ \\
\hline $50-60$ & $0.26 \mathrm{Aa}$ & $0.47 \mathrm{Ab}$ & $0.43 \mathrm{Ac}$ & $0.35 \mathrm{Ac}$ & $1.10 \mathrm{Ac}$ & $0.77 \mathrm{Ab}$ \\
\hline $70-80$ & $0.27 \mathrm{Aa}$ & $0.42 \mathrm{Ab}$ & $0.37 \mathrm{Ac}$ & $0.53 \mathrm{Abc}$ & $1.19 \mathrm{Ac}$ & $0.46 \mathrm{Ab}$ \\
\hline $90-100$ & $0.16 \mathrm{Aa}$ & $0.26 \mathrm{Ab}$ & $0.20 \mathrm{Ac}$ & $0.27 \mathrm{Ac}$ & $0.49 \mathrm{Ac}$ & $0.40 \mathrm{Ab}$ \\
\hline \multicolumn{7}{|c|}{ Medium roots } \\
\hline $0-10$ & $0.01 \mathrm{Da}$ & 0.08 BCDab & 0.12 BCab & $0.19 \mathrm{Aa}$ & 0.11 BCab & $0.03 \mathrm{CDa}$ \\
\hline $10-20$ & $0.03 \mathrm{Ba}$ & $0.03 \mathrm{Bab}$ & $0.08 \mathrm{ABabc}$ & $0.11 \mathrm{ABb}$ & $0.04 \mathrm{Bbc}$ & $0.02 \mathrm{Ba}$ \\
\hline $30-40$ & $0.03 \mathrm{Aa}$ & $0.02 \mathrm{Aab}$ & $0.03 \mathrm{Abc}$ & $0.03 \mathrm{Ac}$ & 0.08 Aabc & $0.02 \mathrm{Aa}$ \\
\hline $50-60$ & $0.01 \mathrm{Aa}$ & $0.00 \mathrm{Ab}$ & $0.02 \mathrm{Abc}$ & $0.03 \mathrm{Ac}$ & $0.01 \mathrm{Ac}$ & $0.03 \mathrm{Aa}$ \\
\hline $70-80$ & $0.01 \mathrm{Aa}$ & $0.01 \mathrm{Ab}$ & $0.01 \mathrm{Ac}$ & $0.02 \mathrm{Ac}$ & $0.04 \mathrm{Abc}$ & $0.01 \mathrm{Aa}$ \\
\hline $90-100$ & $0.02 \mathrm{Aa}$ & $0.00 \mathrm{Ab}$ & $0.02 \mathrm{Abc}$ & $0.01 \mathrm{Ac}$ & $0.03 \mathrm{Abc}$ & $0.00 \mathrm{Aa}$ \\
\hline
\end{tabular}

Means followed by the same uppercase letter (line) and by the same lowercase letter (column), within the same roots class, do not differ by Tukey test at 5\% probability. 
Table 12: Root density - RD ( $\left.\mathrm{g} \mathrm{dm}^{-3}\right)$ of fine and medium roots for the sampled distances and layers.

\begin{tabular}{|c|c|c|c|c|c|c|}
\hline \multirow{2}{*}{$\begin{array}{l}\text { Layer } \\
(\mathrm{cm})\end{array}$} & \multicolumn{6}{|c|}{ Distance $(\mathrm{cm})$} \\
\hline & -110 & -70 & -30 & 30 & 70 & 110 \\
\hline \multicolumn{7}{|c|}{ Fine roots } \\
\hline $0-10$ & $0.48 \mathrm{D} a b$ & $2.05 \mathrm{~B} \mathrm{a}$ & $2.10 \mathrm{~B} \mathrm{a}$ & $2.90 \mathrm{~A} \mathrm{a}$ & $2.59 \mathrm{~A} \mathrm{a}$ & $0.97 \mathrm{Ca}$ \\
\hline $10-20$ & $0.17 \mathrm{C} \mathrm{ab}$ & $0.40 \mathrm{ABC} b$ & $0.53 \mathrm{ABC} b \mathrm{bc}$ & $0.69 \mathrm{ABC} b$ & $0.73 \mathrm{ABC} b \mathrm{~b}$ & $0.30 \mathrm{AB} b$ \\
\hline $30-40$ & $0.10 \mathrm{~B} \mathrm{~b}$ & $0.25 \mathrm{AB} \mathrm{b}$ & $0.32 \mathrm{AB} b \mathrm{bc}$ & $0.29 \mathrm{AB} C$ & $0.55 \mathrm{AB} b c d$ & $0.21 \mathrm{AB} b$ \\
\hline $50-60$ & $0.08 \mathrm{~A} \mathrm{~b}$ & $0.17 \mathrm{~A} \mathrm{~b}$ & $0.16 \mathrm{AC}$ & $0.13 \mathrm{AC}$ & $0.27 \mathrm{~A} \mathrm{~cd}$ & $0.20 \mathrm{~A} \mathrm{~b}$ \\
\hline $70-80$ & $0.11 \mathrm{Ab}$ & $0.13 \mathrm{Ab}$ & $0.10 \mathrm{AC}$ & $0.13 \mathrm{AC}$ & $0.30 \mathrm{~A} \mathrm{~cd}$ & $0.11 \mathrm{~A} \mathrm{~b}$ \\
\hline $90-100$ & $0.07 \mathrm{~A} \mathrm{~b}$ & $0.08 \mathrm{Ab}$ & $0.08 \mathrm{AC}$ & $0.11 \mathrm{AC}$ & $0.16 \mathrm{Ad}$ & $0.13 \mathrm{~A} \mathrm{~b}$ \\
\hline \multicolumn{7}{|c|}{ Medium roots } \\
\hline $0-10$ & $0.08 \mathrm{Ca}$ & $0.52 \mathrm{BC}$ ab & $0.74 \mathrm{ABC} a b$ & $0.9 \mathrm{AB} a$ & $0.43 \mathrm{BC} a$ & $0.10 \mathrm{Ca}$ \\
\hline $10-20$ & $0.19 \mathrm{BC}$ a & 0.08 B b & $0.47 \mathrm{AB} a b c$ & $0.73 \mathrm{~A} a$ & $0.36 \mathrm{AB} a$ & $0.04 \mathrm{Ca}$ \\
\hline $30-40$ & $0.11 \mathrm{~A} \mathrm{a}$ & $0.21 \mathrm{~A} \mathrm{ab}$ & $0.14 \mathrm{~A} \mathrm{bc}$ & $0.16 \mathrm{Ab}$ & $0.42 \mathrm{~A} \mathrm{a}$ & $0.11 \mathrm{~A} \mathrm{a}$ \\
\hline $50-60$ & $0.02 \mathrm{Aa}$ & $0.04 \mathrm{~A} \mathrm{~b}$ & $0.17 \mathrm{~A} \mathrm{bc}$ & $0.08 \mathrm{Ab}$ & $0.13 \mathrm{Aa}$ & $0.22 \mathrm{~A} \mathrm{a}$ \\
\hline $70-80$ & $0.02 \mathrm{~A} \mathrm{a}$ & $0.02 \mathrm{~A} \mathrm{~b}$ & $0.12 \mathrm{~A} \mathrm{bc}$ & $0.05 \mathrm{~A} \mathrm{~b}$ & $0.28 \mathrm{~A} \mathrm{a}$ & $0.03 \mathrm{~A} \mathrm{a}$ \\
\hline $90-100$ & $0.06 \mathrm{~A} \mathrm{a}$ & $0.01 \mathrm{~A} \mathrm{~b}$ & $0.02 \mathrm{~A} \mathrm{C}$ & $0.11 \mathrm{~A} \mathrm{~b}$ & $0.28 \mathrm{~A}$ & $0.04 \mathrm{~A} \mathrm{a}$ \\
\hline
\end{tabular}

Means followed by the same uppercase letter (line) and by the same lowercase letter (column), within the same roots class, do not differ by the Tukey test at $5 \%$ probability.

\section{CONCLUSIONS}

Coffee plants subjected to lower $\mathrm{N}$ and $\mathrm{K}_{2} \mathrm{O}$ levels presented more developed root systems. Higher concentration of roots was observed in the superficial layers and under the dripline, where fertilizers were applied by fertigation.

\section{ACKNOWLEDGEMENTS}

The authors thank the Foundation for Research of the State of Minas Gerais (FAPEMIG), and the National Council for Scientific and Technological Development $(\mathrm{CNPq})$ for the scholarships and financial support of this research.

\section{REFERENCES}

ALLEN, R. G. et al. Evapotranspiración del cultivo Guías para la determinación de los requerimientos de agua de los cultivos. Roma: Estudio FAO Riego y Drenaje, 2006. 323p.

ALVES, J. D. et al. Source-sink manipulations in Coffea arabica $\mathrm{L}$. and its effect on growth of shoots and root system. Ciência e Agrotecnologia. 35(5):956-964, 2011.
BARRETO, C. V. G. et al. Distribuição espacial do sistema radicular do cafeeiro fertirrigado por gotejamento em Campinas. Bragantia. 65:641-647, 2006.

CARVALHO, A. M. et al. Correlação entre crescimento e produtividade de cultivares de café em diferentes regiões de Minas Gerais, Brasil. Pesquisa Agropecuaria Brasileira. 45(3):269-275, 2010.

CASSIDY, D. M. S.; KUMAR, D. Root distribution of Coffea arabica L. in Zimbabwe. I. The effect of plant density, mulch, cova planting and shade in Chipinge. Zimbabwe Journal of Agricultural Research. 22:119-132, 1984.

DOMINGHETTI, A. W. et al. Doses de fósforo e irrigação na nutrição foliar do cafeeiro. Revista Brasileira de Engenharia Agrícola e Ambiental. 18(12):1235-1240, 2014.

GARRIZ, P. I. Distribuición radicular de três cultivares de Coffea arábica L. de 24 años de edad, em um suelo limo-arcilloso. Cencias de la Agricultura. 2:65-76, 1978.

GUAN, D. et al. Tillage practices effect on root distribution and water use efficiency of winter wheat under rainfed condition in the North China Plain. Soil \& Tillage Research. 146(1):286-295, 2015. 
GUIMARÃES, R.J. et al. Adubação para primeiro ano pós-plantio ( $\mathrm{N} \mathrm{e} \mathrm{K}_{2} \mathrm{O}$ ) de cafeeiros fertirrigados na região sul de Minas Gerais. Coffee Science. 5(2):137-147, 2011.

KELLER, J.; BLIESNER, R. D. Sprinkle and trickle irrigation. New York: van Nostrand Reinhold, 1990. 652p.

KUMAR, D. Some aspects of the physiology of Coffea arábica L. A review. Kenya Coffee. 44:9-47, 1979.

MANTOVANI, E. C. et al. Eficiência no uso da água de duas cultivares de batata-doce em resposta a diferentes lâminas de irrigação. Horticultura Brasileira. 31(4):602-606, 2013.

MOTTA, A. C. V. et al. Distribuição horizontal e vertical da fertilidade do solo e das raízes de cafeeiro (Coffea arabica L.) cultivar Catuaí. Acta Scientiarum. Agronomy. 28:455-463, 2006

PARTELLI, F. A. et al. Produção e desenvolvimento radicular de plantas de café 'Conilon' propagadas por sementes e por estacas. Pesquisa Agropecuária Brasileira. 41(6):949954, 2006.

PEREIRA, M. G. et al. Carbono, matéria orgânica leve e fósforo remanescente em diferentes sistemas de manejo do solo. Pesquisa Agropecuária Brasileira. 45(5):508-514, 2010.

QUANQI, L. et al. Root growth, available soil water, and wateruse efficiency of winter wheat under different irrigation regimes applied at different growth stages in North China. Agricultural Water Management. 97(10):1676-1682, 2010.

RENA, A. B.; DAMATTA, F. M. O sistema radicular do cafeeiro: Estrutura e ecofisiologia. In: ZAMBOLIN, L. O estado da arte de tecnologias na produção de café. Viçosa: UFV, 2002. p.11-92.
RENA, A. B.; GUIMARÃES, P. T. G. Sistema radicular do cafeeiro: Estrutura, distribuição, atividade e fatores que o influenciam. Belo Horizonte: Epamig, 2000. 80p.

REZENDE, R. et al. Crescimento inicial de duas cultivares de cafeeiro em diferentes regimes hídricos e dosagens de fertirrigação. Engenharia Agrícola. 30(3):447-458, 2010.

RONCHI, C. P. et al. Morfologia radicular de cultivares de café arábica submetidas a diferentes arranjos espaciais. Pesquisa Agropecuária Brasileira. 50(3):187-195, 2015.

SAKAI, E. et al. Coffee productivity and root systems in cultivation schemes with different population arrangements and with and without drip irrigation. Agricultural Water Management. 148(1):16-23, 2015.

SANTINATO, R.; FERNANDES, A. L. T. Cultivo do cafeeiro irrigado em plantio circular sob pivô central. Belo Horizonte: O Lutador, 2002. 251p.

SILVA, V. A. et al. Resposta fisiológica de clone de café Conilon sensível à deficiência hídrica enxertado em porta-enxerto tolerante. Pesquisa Agropecuária Brasileira. 45(5):457464, 2010.

SILVEIRA, H. R. O. et al. Gas exchange and carbohydrate partitioning in coffee seedlings under waterlogging. Ciência e Agrotecnologia. 39(2):138-146, 2015.

SOARES, A. R. et al. Produção e distribuição de raízes em cafeeiros irrigados por gotejamento. Engenharia na Agricultura. 15(2):130-140, 2007.

SOBREIRA, F. M. et al. Adubação nitrogenada e potássica de cafeeiro fertirrigado na fase de formação, em plantio adensado. Pesquisa Agropecuária Brasileira. 46(1):916, 2011. 